\title{
Persepsi Wisatawan Daerah Terhadap Pengembangan Wisata Alam Lava Bantal, Berbah, Sleman, Yogyakarta
}

\author{
Wisnu Hadi \\ Akademi Pariwisata BSI Yogyakarta \\ Email : wisnu.wsh@bsi.ac.id
}

\begin{abstract}
Tourism is an activity that directly gives, touches and involves the community so as to have an impact on the local community, Tourism now has become a necessity for people in various layers not just for certain circles only. It is natural that tourism development is needed so that the potential and attractions can be famous. One of nature tourism potential and education is in Lava Bantal natural tourism in Berbah, Sleman Kabupeten where this tour has developed and save a lot of natural potential that can be a tourist education. In this qualitative descriptive study of respondents consisting of local tourists found that tourists assess this tourism object has a strategic access road location so easy to visit. In addition the facilities-prasana factors are available with good and adequate. The atmosphere factor is beautiful and comfortable giving the visitor satisfaction to linger in the tourism object. Interview results can also be known that the manager is also always trying to keep the aspects of cleanliness and security of visitors to make tourists feel satisfied with the condition although there is little shortage in its management. The conclusion of the perception of the tourists who have visited the attractions they are eager to return to the tourist attraction is very dominant answer tertanyaan from questionnaire research. So that makes the manager responsible for developing Lava Pillow tourism for the better future
\end{abstract}

Keywords: Perception, Development and Tourists

Abstrak: Pariwisata adalah suatu kegiatan yang secara langsung memberi, menyentuh dan melibatkan masyarakat sehingga membawa dampak terhadap masyarakat setempat., Pariwisata sekarang telah menjadi kebutuhan bagi masyarakat di berbagai lapisan bukan hanya untuk kalangan tertentu saja. Sangatlah wajar perlu pengembangan pariwisata agar potensi dan daya tarik wisata dapat terkenal. Salah satu potensi wisata alam dan pendidikan ada di wisata alam Lava Bantal yang ada di Berbah, Kabupeten Sleman dimana wisata ini telah berkembang dan menyimpan banyak potensi alam yang dapat menjadi wisata pendidikan.Dalam penelitian deskriptif kualitatif ini responden yang terdiri dari wisatawan lokal didapat bahwa wisatawan menilai obyek wisata ini mempunyai akses jalan yang strategis lokasinya sehingga mudah dikunjungi. Selain itu faktor sarana-prasana sudah tersedia dengan baik dan memadai. Faktor suasana yang asri dan nyaman memberi kepuasaan pengunjung untuk berlama di obyek wisata tersebut. Hasil wawancara juga dapat diketahuai bahwa pengelola juga selalu berupaya menjaga dari aspek kebersihan dan keamanan pengunjung membuat wisatawan merasa puas dengan kondisi tersebut meski ada sedikit kekurangan dalam pengelolaannya. Kesimpulan dari persepsi para wisatawan yang telah berkunjung ke obyek wisata tersebut mereka berhasrat untuk berkunjung kembali ke obyek wisata tersebut sangat dominan menjawab tertanyaan dari kuesioner penelitian. Sehingga membuat pengelola bertanggungjawab untuk mengembangkan wisata Lava Bantal agar lebih baik kedepannya

Kata Kunci : Persepsi, Pengembangan dan Wisatawan.

\subsection{Latar Belakang}

Perkembangan ekonomi saat ini mulai menunjukkan grafik yang memberi gambaran meningkat atau progresif, hal ini dikarenakan faktor keamanan yang baik serta kondisi daerah yang relatif stabil. Dunia perdagangan dan investasi mulai menunjukkan gairah yang maju hal ditandai perkembangan pembangunan daerahnya sangat pesat.

Salah pembangunan ekonomi yang menjadi fokus pemerintah pusat dan daerah adalah pembangunan sektor pariwisata.Perkembangan pariwisata dewasa ini sangat pesat dan memberikan peluang terhadap pertumbuhan ekonomi nasional maupun regional. Untuk itu pembangunan pariwisata terus dipacu dan pemerintah mempunyai keyakinan bahwa pariwisata dapat menjadi sektor andalan menggantikan minyak dan gas bumi yang selama ini menjadi tumpuan pemerintah dalam menunjang penerimaan negara

Setiap propinsi, kabupaten dan kota di Indonesia berlomba-lomba membangun potensi pariwisata yang selama ini tidak terkenal mulai menunjukkan dibuka dan diekspose ke luar daerah atau negeri. Dengan bantuan teknologi informasi khususnya media sosial daerah yang tidak dikenal menjadi terkenal.

Pariwisata adalah suatu kegiatan yang secara langsung memberi, menyentuh dan melibatkan masyarakat sehingga mambawa dampak terhadap masyarakat ISSN : 2087-0086 
setempat(pitana, 108:2005). Pariwisata juga menyentuh berbagai aspek kehidupan masyarakat antara lain sosial ekonomi, sosial budaya, dan lingkungan. Selain itu menurut Endang Tjitroresmi bahwa industri pariwisata tidak hanya terkait pada atraksi wisata, tetapi juga terkaitdengan industri lain, seperti perhotelan, restoran, angkutan (darat, laut, dan udara) dan produk-produk industri lainnya(105:2003)..

Salah satu daerah di Propinsi Yogyakarta yaitu Kabupaten Sleman yang mempunyai potensi wisata yang luar biasa selalu menjadi tujuan wisata baik wisata nusantara dan asing. Daerah yang memiliki potensi wisata alam, budaya dan kuliner telah dikenal sampai ke dunia internasional. Dengan penerbangan langsung dari Yogyakarta ke Singapura serta Malaysia banyak turis berkunjung ke Yogyakarta khususnya di obyek wisata di Kabupaten Sleman.

Menurut Kepala Dinas Pariwisata Kabupaten Sleman, Sudarningsih menjelaskan tercatat sebanyak 6.390 .963 wisatawan mengunjungi Kabupaten Sleman hingga akhir Oktober ini. Rinciannya 6.068.780 atau 95,41 persen merupakan kunjungan wisatawan nusantara dan 292.180 atau 4,59 persen merupakan kunjungan wisatawan mancanegara.

Pada berita di harian Jogya Tribunnews bahwa Candi memberi sumbangan 42,48 persen kunjungan wisatawan, disusul kunjungan wisata alam sebesar 24,34 persen, dan kunjungan museum mencapai 13,84 persen dan sisanya sebesar $19,33 \%$ ke desa wisata dan event-event yang ada di Kabupaten Sleman.

Salah satu obyek wisata alam yang sedang berkembang selama 2 tahun terakhir ini di daerah Kabupaten Sleman adalah obyek wisata Lava Bantal yang ada di Desa Jogotirto, Kecamatan Berbah, Kabupaten Sleman. Obyek alam dengan keindahaan sungai dengan dilengkapi batu-batu alam yang diperkirakan usian juta tahun.

Obyek wisata ini selalu dikunjungi wisatawan lokal maupun luar daerah karena lokasinya yang strategis serta didukung sarana-prasarana yang membuat wisatawan tertarik untuk berkunjung. . Ketertarikan wisatawan ketika berkunjung tentunya akan menciptakan persepsi yang positif, maka suatu objek wisata dituntut untuk memenuhi keinginan wisatawan (Pitana dan Gayatri, 2005). Seberapa besar keinginan pasar, diperlukan suatu analisis persepsi karena persepsi terhadap kuliatas objek yang menjadi tolok ukur untuk melihat tingkat mutu suatu objek. Untuk itu persepsi wisatawan terhadap obyek wisata alam Lava Bantal menarik untuk diteliti sejauh mana pengembangan wisata telah berjalan dan berhasil meningkatkan kunjungan wisatawan.

\subsection{Tinjauan Pustaka}

\subsubsection{Pengertian Pariwisata}

Kegiatan Pariwisata merupakan kebutuhan manusia yang tidak terpisahkan dalam hidupnya sehingga permintaan untuk melakukan perjalanan setiap waktu selalu meningkat. Sehingga Pariwisata merupakan kegiatan yang telah menjadi tuntutan pada jaman sekarang dan itu terjadi disetiap negara yang mempunyai alam yang menarik untuk dikunjungi.

Menurut Salah Wahab bahwa Pariwisata adalah suatu aktivitas manusia yang dilakukan secara sadar yang mendapat pelayanan secara bergantian diantara orang-orang dalam suatu negara itu sendiri atau luar negeri untuk mencari kepuasaan yang beraneka ragam dan berbeda dengan apa yang dialaminya dimana seseorang memperoleh pekerjaan tetap(1997:107).

\subsubsection{Pengembangan Pariwisata}

Pariwisata tidak lepas adanya dorongan naluri manusia yang selalu ingin mengetahui dan mencari hal-hal yang baru, bagus, menarik serta mengagumkan serta mungkin menentang. Sehingga membuat wisatawan untuk mendatangi tempat-tempat tersebut sehingga pemerintah daerah maupun pusat selalu melakukan pengembangan wisatanya sehingga terus ingin dikunjungi.

Menurut Gamal Siswantoro (2001:25) bahwa pengembangan pariwisata merupakan perkenalan nilai budaya bangsa dan meningkatkan kualitas budaya nasional dengan memperhatikan tetap terpeliharannya kebudayaan nasional dengan memperhatikan tetap terpeliharannya kebudayaan bangsa, kelestarian dan mutu lingkungannya.

Untuk mengembangkan pariwisata khususnya obyek wisata harus memperhatikan terpeliharannya kebudayaan dan kelestarian budaya. Hal ini juga dikemukan oleh Saleh Wahab (1989 :23), bahwa dalam pengembangan pariwisata diharuskan untuk memberikan atau mempersiapkan tempat bagi pengunjung supaya dapat menikmati obyek wisata tersebut dengan puas. PERDA Propinsi DIY No. 4 tahun 1999 pasal 15 tentang rencana induk pengembangan pariwisata daerah dalam Yulianto (2016:12), menyebutkan bahwa pengembangan produk pariwisata merupakan suatu kegiatan untuk meningkatkan kuantitas dan kualitas komponen Produk Pariwisata, yang terdiri atas 
kegiatan perencanaan, pelaksanaan, evaluasi dan pemantauan komponen produk pariwisata yang meliputi objek dan daya tarik wisata, usaha sarana pariwisata, sarana dan prasarana, sumber daya manusia, kelembagaan, fasilitas penunjang, dan lingkungan.

Pengembangan Pariwisata harus merupakan pengembangan berencana secara menyeluruh sehingga dapat diperoleh manfaat yang optimal bagi masyarakat, baik dari segi ekonomi, sosial maupun kultur. Rencana tersebut harus mampu memberikan kerangka kerja kebijaksanaan pemerintah untuk mendorong dan mengendalikan pengembangan pariwisata.

Keberhasilan dalam pengembangan suatu obyek wisata agar selalu menjadi tempat kunjungan wisatawan dapat dilakukan dengan pendekatan atraksi, aksesibilitas, amenitas dan aktivit selain itu juga melakukan analisis SWOT yaitu kelebihan, kekurangan,kesempatan dan ancaman terhadap obyek wisata tersebut.

\subsubsection{Pembangunan Pariwisata Di}

\section{Indonesia}

Dalam Undang-Undang No. 10 Tahun 2009 bahwa penyelenggaraan kepariwisataan di Indonesia haruslah berdasarkan asas manfaat, kekeluargaan, adil dan merata, keseimbangan, kemandirian, kelestarian, partisipasif, berkelanjutan, demokratis, kesetaraan dam kesatuan, yang semuanya diwujudkan melalui pelaksanaan rencana pembangunan pariwisata dengan memperhatikan keanekaragaamaan, keunikan dan kekhasan budaya dan alam, serta kebutuhan manusia untuk berwisata.

Dalam pembangunan Pariwisata di Indonesia ada tujuan yang hendak dicapai dalam kepariwisataan adalah sebagai berikut :

1. Meningkatkan pertumbuhan ekonomi

2. Meningkatkan kesejahteraan rakyat

3. Menghapus kemiskinan

4. Mengatasi pengangguran

5. Melestarikan alam, lingkungan dan sumber daya

6. Memajukan kebudayaan

7. Mengangkat citra bangsa

8. Memupuk cinta tanah air

9. Memperkukuh jati diri dan kesatuan bangsa

10. Mempererat persahabatan antar bangsa Menurut Undang-Undang No. 10 Tahun

2009 terdapat tiga komponen pelaku usaha dan pemangku kepentingan pengembangan pariwisata di Indonesia, yaitu :

1. Pihak Pemerintah Pusat dan Daerah

2. Swasta/industry baik investor asing ataupun pelaku industry dalam negeri
3. Masyarakat yang terkait baik sebagai tenaga kerja, pelaku kegiatan usaha kepariwisataan maupun sebagai tuan rumah.

\subsubsection{Pengertian Wisatawan dan Obyek} Wisata

Wisata menurut Norval dari Negara Inggris adalah kegiatan yang berhubungan dengan masuk, tinggal dan bergeraknya penduduk asing di dalam atau luar suatu negara atau wilayah (M.Kesrul, 2003). Kemudian pengertian wisatawan menurut Fandeli (1995) diartikan seseorang yang melakukan perjalanan dan persinggahan sementara diluar tempat tinggalnya untuk jangka waktu lebih dari 24 jam dengan maksud untuk tidak mencari nafkah.

Kemudian pengertian obyek wisata dapat diartikan segala sesuatu yang menarik dan bernilai untuk dikunjungi serta dilihat sebagai aktraksi (Pendit,1986). Sedangkan menurut Fandeli(1995) diartikan budaya yang terdapat di dalam brosur pariwisata budaya dan sejarah

\subsubsection{Pengertian Persepsi}

Dalam Kamus Besar Bahasa Indonesia (1991: 759) kata persepsi mempunyai arti tanggapan (penerimaan) langsung dari suatu serapan, proses seseorang mengetahui beberapa hal melalui panca inderanya.

Seangkan menurut Walgito ( $2003: 46$ ) persepsi itu merupakan proses pengorganisasian, penginterprestasian terhadap stimulus yang diterima oleh organisme atau individu sehingga merupakan sesuatu yang berati, dan merupakan aktifitas yang terinterated dalam diri individu.

Kemudian menurut Walgito ( 2003 : 128

) aspek - aspek persepsi menurutnya ada beberapa yaitu :

1. Aspek kognitif

Komponen ini tersusun atas dasar pengetahuan atau informasi yang dimiliki seseorang tentang objek.

2. Aspek afektif

Komponen afektif berhubungan dengan rasa senang dan tidak senang, jadi sifatnya evaluatif yang berhubungan erat dengan nilai - nilai kebudayaan atau sistem nilai yang dimilikinya.

3. Aspek konatif

Merupakan kesiapan seseorang untuk bertingkah laku yang berhubungan dengan objek sikapnya.

\subsection{Metode Penelitian}

Dalam penelitian tentang persepsi wisatawan mengenai obyek wisata peneliti menggunakan metode diskriptif kualitatif. Metode ini digunakan untuk mengetahui 
gambaran atau lukisan secara sistematis dan akurat mengenai fakta-fakta, sifat-sifat serta hubungan antar fenomena yang diselidiki.

Sedangkan untuk analisa data peneliti menggunakan analisis disktiptif kualitatif yaitu dengan memberikan ulasan atau interpretasi terhadap data yang diperoleh sehingga menjadi lebih jelas dan bermakna dengan sekedar angka-angka.

Sedangkan teknik pengumpulan data dari sumber data primer dan sekunder dimana data primer adalah informasi yang diperoleh dari sumber-sumber primer yaitu yang asli, informasi dari tangan pertama atau responden (Wardiyanta, 2006:28). Dalam penelitian ini tentang informasi langsung dari pihak pengelola wisata alam Lava Bantal, Kecamatan Berbah, Kabupaten Sleman, DIY. Sedangkan data sekunder adalah informasi yang diperoleh tidak secara langsung dari responden, tetapi dari pihak ketiga (Wardiyanta, 2006:28). Penggunaan data sekunder ini dapat menguntungkan bagi penulis karena dapat menghemat waktu, tenaga dan dana.

Untuk mendapatkan hasil penelitian yang mendekati kebenaran maka digunakan instrumen sebagai berikut:

1. Wawancara langsung

Metode wawancara adalah proses tanya jawab dalam penelitian yang berlangsung secara lisan. Penulis melakukan wawancara terhadap pelaku wisata yaitu kepala dan anggota kelompok sadar wisata sebagai pengelola wisata alam Lava Bantal serta sejumlah wisatwan atau pengunjung yang berkunjung di obyek wisata tersebut.

2. Kuesioner

Kuesioner merupakan alat pengumpulan data dengan membuat daftar pertanyaan yang diisi oleh wisatawan yang saat berkunjung di wisata alam Lava, Kecamatan Berbah, Kabupaten Sleman.

3. Pengamatan langsung (direct obsevation) Metode Observasi yaitu cara memperoleh data yang dilakukan dengan cara mengamati dan mencatat secara sistematisk gejala- gejala yang diselidiki. Dengan meninjau kegiatan-kegiatan dan kondisi yang ada di wisata alam Lava Bantal, Kecamatan Berbah, Kabupaten Sleman tersebut supaya penulis dapat melihat dengan jelas bagaimana keadaannya.

4. Dokumentasi

Dokumentasi ini dilakukan guna mendapatkan foto atau gambar kegiatan wisata alam Lava Bantal,, Kecamatan Berbah, Kabupaten Sleman.
5. Studi Pustaka

Studi Pustaka dilakukan untuk mencari dan mendapatkan data-data yang bersifat teoritis dan berhubungan dengan penelitian yang sedang dilakukan. Dengan mempelajari literatur-literatur, dan sumber-sumber lainnya dari internet yang berhubungan dengan penelitian. Pengumpulan data kepustakaan dilakukan terhadap data dan informasi dalam bentuk buku, laporan hasil penelitian dan sumber lainnya.

Analisis data yang digunakan dalam penelitian ini adalah analisis deskriptif, kualitatif yang pengujiannya bertitik tolak dari data yang telah terkumpul kemudian dilakukan penarikan kesimpulan. Untuk analisa data peneliti menggunakan metode statistik deskriptif yang berbentuk tabel-tabel frekuensi. Data kualitatif dan kuantitatif yang terkumpul ditabulasi, diklasifikasi, diolah dan dianalisis kemudian diinterpretasikan untuk menentukan kesimpulan dan rekomendasi kepada pengelola wisata alam Lava Bantal Kecamatan Berbah, Kabupaten Sleman, Daerah Istimewa Yogyakarta untuk mengelola destinasi wisata dengan sebaik-baiknya.

\subsection{Hasil Dan Pembahasan}

\subsubsection{Profile Obyek Wisata Lava Bantal}

Daerah Istimewa Yogyakarta sebagai daerah tujuan wisata setelah pulau Bali mempunyai potensi wisata khususnya alam. Dengan luas wilayah yang berhadapan langsung dengan Samudra Hindia di sebelah selatan dan Gunung dan Pegunungan disebelah utara serta Barat menjadikan Yogyakarta diunggulkan dengan wisata alamnya.

Kabupaten Sleman sebagai bagian dari Provinsi Daerah Istimewa Yogyakarta mempunyai banyak potensi wisata khususnya wisata alam di lereng gunung Merapi yang sudah terkenal di Indonesia seperti Kaliurang, Lava Tour dan Lava Bantal dan lain-lain. Obyek wisata yang baru berkembang dan dirintis oleh Pemda Sleman serta Pemerintah Desa Jogotirto, Kecamatan Berbah adalah wisata alam Lava Bantal.

Lava Bantal yang baru diresmikan tahun 2016 oleh Gubernur Sultan Hamengkubowono $X$ saat ini telah menjadi wisata yang menarik pengunjung wisatawan daerah dan nasional. Sejak dibuka menjadi wisata alam dan pendidikan menjadi tempat untuk berkunjung wisatawan sekedar rekerasi atau melakukan penelitian. Obyek wisata ini terkenal dengan batuan yang menyerupai bantal dan terbentuk jutaan tahun yang lalu. Peneliti banyak berdatangan untuk belajar tentang batuan 
yang terbentuk dari lava yang sudang membeku dan menjadi batu. Selain itu aliran sungai Opak juga dimanfaatkan untuk wisata air seperti wisata tubing dan bermain air atau mandi disungai.

Obyek wisata Lava Bantal ini terletak di pinggir sungai Opak sehingga menjadikan wisata ini dikembangkan menjadi wisata air sehingga lengkap sudah wisata ini dikembangkan menjadi wisata alam dan pendidikan. Obyek ini juga lokasinya sangat strategis karena tidak jauh dari Bandaralnternasional Adisucipto serta Candi Prambanan dan Boko. Lokasi yang strategis inilah menajadikan obyek ini ramai dikunjungi dan menjadi tempat tujuan setelah wisatawan berkunjung dari Candi Prambanan dan Candi Boko.

Sejak diresmikan tahun 2015 obyek wisata Lava Bantal terus mengalami perkembangan fasilitas sehingga wisatwan sangat betah untuk menikmati pemandangan yang asri dan sejuk karena ada dipinggir sungai Opak. Pemerintah desa Jogotirto dalam hal ini perangkatnya dan warga masyarakatnya bahu membahu mengembangkan wisata ini. Promosi obyek wisata terus menerus disertai perbaikan akses jalan, parkir kendaraan telah dilakukan untuk membuat nyaman pengunjung.

\subsubsection{Data Identitas Pengunjung Wisata Alam Lava Bantal}

Dalam penelitian tentang persepsi wisatawan yang berkunjung atau yang sudah berkunjung di obyek wisata alam Lava Bantal, peneliti menggunakan teknik pengambilan data wawancara dan angket. Angket yang berisi pertanyaan tentang pengembangan wisata alam Lava Bantal diberikan kepada wisatawan yang menikmati pemandangan di obyek wisata alam tersebut. Sebanyak 60 responden yang memberikan penilaian tentang persepsi pengambangan wisata alam Lava Bantal ini. Data yang dapat dianalisis adalah sebagai berikut.

Tabel 1: Data Karakteristik Pengunjung

\begin{tabular}{|c|l|c|c|}
\hline Keterangan & Keterangan & Frek & Persentase \\
\hline Jenis Kelamin & Pria & 23 & $38,3 \%$ \\
\hline & Wanita & 37 & $61,6 \%$ \\
\hline & Total & 60 & $100 \%$ \\
\hline & $<17$ Tahun & 13 & 21,6 \\
\hline & 17-25 Tahun & 21 & $35 \%$ \\
\hline & 26-35 tahun & 16 & $26 \%$ \\
\hline & 36-45 Tahun & 7 & $11,6 \%$ \\
\hline & 46-55 Tahun & 2 & $3,3 \%$ \\
\hline & $>55$ Tahun & 1 & $1,6 \%$ \\
\hline & Total & 60 & $100 \%$ \\
\hline
\end{tabular}

Untuk data pengunjung sebanyak 60 responden sebanyak $61,6 \%$ adalah wanita dan sisanya $38,3 \%$ berjenis kelamin pria saat penelitian dilakukan di obyek wisata Lava
Bantal tersebut. Untuk data usia yang pengunjung atau wisatawan yang dating saat penelitian dari 60 responden adalah anak muda atau remaja dimana datanya sebanyak $35 \%$ dimana usia sekitar umur 17-25 tahun. Kemudian usia 26 -35 tahun sebanyak 26\%.

Dengan demikian bahwa pengunjung obyek wisata alam Lava Bantal ternyata didominasi anak muda atau remaja karena wisata ini lebih cocok untuk wisata pendidikan dan air. Sebagai wisata pendidikan karena wisata alam ini digunakan untuk belajar sambil penelitian tentang batuan yang disebut lava bantal yang usianya ratusan juta tahun. Wisatawan anak muda atau remaja juga banyak memanfaatkan wisata di obyek wisata ini untuk wisata tubing atau susur sungai menggunakan ban mobil dengan pemandu dari pemuda yang terlatih serta professional sehingga keamanan dapat terjaga. Kemudian banyak juga keluarga muda yang mengajak anak-anaknya bermain air sungai di obyek wisata ini.

Tabel 2 : Data Tingkatan Pendidikan Pengunjung

\begin{tabular}{|c|l|c|c|}
\hline No. & Keterangan & Frek & Persentase \\
\hline 1 & Tidak Sekolah & 1 & $1.6 \%$ \\
\hline 2 & SD & 1 & $1,6 \%$ \\
\hline 3 & SMP & 8 & $13 \%$ \\
\hline 4 & SMA/SMK & 30 & $50 \%$ \\
\hline 5 & $\begin{array}{l}\text { Perguruan } \\
\text { Tinggi }\end{array}$ & 20 & $33 \%$ \\
\hline & Total & 60 & $60 \%$ \\
\hline
\end{tabular}

Untuk profile pengunjung berdasarkan tingkat pendidikan rata-rata mengeyam pendidikan SMA/SMK sebanyak $50 \%$ dan $33 \%$ berpendidikan perguruan tinggi, artinya wisata ini banyak didominasi anak muda yang ingin belajar atau melakukan penelitian tentang obyek wisata alam Lava Bantal karena mempunyai nilai arkelogi yang tinggi.

Selain itu banyak anak muda yang usia sekolah dan belajar di perguruan tinggi datang ke obyek wisata alam Lava Bantal menikmati pemandangan yang masih alami dan spot foto yang menarik untuk berfoto ria.

Tabel 3 : Data Asal Daerah Pengunjung

\begin{tabular}{|c|l|c|c|}
\hline No. & \multicolumn{1}{|c|}{ Keterangan } & Frek & Persentase \\
\hline 1. & Kabupaten Sleman & 21 & $35 \%$ \\
\hline 2. & Kabupaten Bantul & 17 & $17 \%$ \\
\hline 3. & Kabupaten Kulon Progo & 0 & $0 \%$ \\
\hline 4. & Kabupaten Gunung Kidul & 1 & $1,6 \%$ \\
\hline 5. & Kota Yogyakarta & 6 & $10 \%$ \\
\hline 6. & Luar Propinsi DIY & 15 & $25 \%$ \\
\hline & Total & 60 & $100 \%$ \\
\hline
\end{tabular}

Data pengunjung wisatawan di obyek wisata alam Lava Bantal bahwa pengunjung yang berasal dari Kabupaten Sleman masih mendominasi yaitu 35\% dikarenakan obyek wisata ini berada di daerah Kabupaten Sleman. Kemudian dari wilayah Kabupaten Bantul ada $17 \%$ pengunjung dimungkinkan 
karena obyek wisata ini juga berdekatan dengan wilayah Kabupaten Bantul. Untuk pengunjung luar Propinsi DIY ada 25\% wisatawan dimana mereka datang memperoleh informasi dari internet atau informasi saudaranya yang tinggal di Yogyakarta.

\subsubsection{Persepsi Pengunjung Terhadap Pengembangan Wisata Alam Lava Bantal \\ Pengunjung wisata alam Lava Bantal} yang berkunjung di obyek wisata ini memberikan penilaian terhadap pengembangan wisata ini memiliki beragam penilaian sesuai persepsi saat mereka melihat segala sesuatu yang dilihat dan dirasakan. Saat penilaian terhadap pengembangan wisata alam ini pengunjung menilai berdasarkan persepsi bahwa obyek wisata sangat menarik untuk dikunjungi lagi karena berbagai alasan. Salah satu alasannya obtek wisata ini masih alami dengan pemandangannya yang sejuk dan nyaman. Dalam penyebaran kuesioner sejumlah pengunjung memberikan penilaian berdasarkan persepsi sebagai berikut :

Tabel 4 :Informasi Tentang Obyek Wisata Alam Lava Bantal

\begin{tabular}{|c|l|c|c|}
\hline No. & Keterangan & Frek & Persentase \\
\hline 1 & Teman & 37 & $61,6 \%$ \\
\hline 2 & Biro Perjalanan & 0 & $0 \%$ \\
\hline 3 & Brosur & 0 & $0 \%$ \\
\hline 4 & Internet & 15 & $25 \%$ \\
\hline 5 & Lain-lain & 8 & $13 \%$ \\
\hline & Jumlah & 60 & $100 \%$ \\
\hline
\end{tabular}

Dalam hal informasi mengenai obyek wisata ini wisatawan mendapat informasi dari teman sebanyak $61,6 \%$ artinya mereka berkunjung ke obyek wisata ini karena ada teman yang telah berkunjung dan menginformasikan ke orang lain. Kemudian dari internet ada $25 \%$ pengunjung yang memperoleh informasi tersebut. Dengan demikian bahwa informasi tentang obyek wisata alam Lava Bantal kebanyakan dari orang yang telah berkunjung dan memberi rekomendasi ke orang lain. Selain media sosial juga berpengaruh.

Tabel 5 : Frekuensi Wisatawan Berkunjung Di Obyek Wisata Alam Lava Bantal

\begin{tabular}{|c|c|c|c|}
\hline No. & Keterangan & Frek & Persentase \\
\hline 1. & Satu Kali & 23 & $38 \%$ \\
\hline 2. & Dua Kali & 11 & $18,3 \%$ \\
\hline 3. & $\begin{array}{l}\text { Lebih dari Dua } \\
\text { Kali }\end{array}$ & 26 & $43,3 \%$ \\
\hline & Jumlah & 60 & $100 \%$ \\
\hline
\end{tabular}

Pengunjung wisata alam Lava Bantal ini ternyata pengunjung yang sudah berulang kali berkunjung ke wisata ini ini dilihat dari data ada $43,3 \%$ yang lebih dari dua kali berkunjung dan hanya $38 \%$ baru sekali berkunjung. Alasan mereka berkunjung karena obyek wisata masih baru dan menarik untuk dikunjungi sebagai wisata air dan pendidikan khususnya penelitian.

Tabel 6 : Waktu Berkunjung Wisatawan Selama Di Obyek Wisata Alam Lava Bantal

\begin{tabular}{|c|c|c|c|}
\hline No. & Keterangan & Frek & Persentase \\
\hline 1. & 1 Jam & 25 & $41 \%$ \\
\hline 2. & $2 \mathrm{Jam}$ & 16 & $26 \%$ \\
\hline 3. & 3 Jam & 16 & $26 \%$ \\
\hline 4. & $>$ 4 Jam & 3 & $5 \%$ \\
\hline & Jumlah & 60 & $100 \%$ \\
\hline
\end{tabular}

Saat wisatawan menikmati obyek wisata alam ini rata-rata lama berkunjung menghabiskan waktu 1 jam ada $41 \%$ orang dan 2 dan 3 jam masing-masing ada 26\% orang dan yang lebih dari 3 jam hanya ada $5 \%$ orang saja. Dengan demikian banyak wisatawan menghabiskan waktu diobyek wisata ini untuk menikmati pemandangan dan bermain air di sungai yang mengalir di obyek wisata ini.

Tabel 7 : Jenis Kegiatan wisatawan Saat berkunjung di Wisata Alam Lava Bantal

\begin{tabular}{|c|l|c|c|}
\hline No. & Keterangan & Frek & Persentase \\
\hline 1. & $\begin{array}{l}\text { Memandang } \\
\text { Panorama }\end{array}$ & 33 & $55 \%$ \\
\hline 2. & Rivertubing & 6 & $6 \%$ \\
\hline 3. & Berjalan-jalan & 11 & $18,3 \%$ \\
\hline 4 & Memancing & 0 & $0 \%$ \\
\hline 5 & Penelitian & 0 & $0 \%$ \\
\hline 6 & Lain-lain & 10 & $16,6 \%$ \\
\hline & Jumlah & 60 & $100 \%$ \\
\hline
\end{tabular}

Sesuai data pada tabel 6 diatas bahwa pengunjung yang menghabiskan waktu berkunjung kebanyakan menikmati atau memandang panorama yaitu sebanyak 55\% wisatawan. Kemudian waktu yang digunakan untuk berjalan-jalan $18,3 \%$ orang dan $6 \%$ orang untuk bermain air atau rivertubing. Dengan demikian wisatawan banyak melakukan kegiatan menikmati pemandangan dan bermain air.

Tabel 8 : Hal yang menarik wisatawan untuk berkunjung di Wisata Alam Lava Bantal

\begin{tabular}{|c|l|c|c|}
\hline No. & \multicolumn{1}{|c|}{ Keterangan } & Frek & Persentase \\
\hline 1. & $\begin{array}{l}\text { Panorama } \\
\text { alamnya yang } \\
\text { alami }\end{array}$ & 54 & $90 \%$ \\
\hline 2. & $\begin{array}{l}\text { Atraksi } \\
\text { rivertubing }\end{array}$ & 0 & $0 \%$ \\
\hline 3. & Atraksi budaya & 0 & $0 \%$ \\
\hline 4. & Masyarakatnya & 0 & $0 \%$ \\
\hline 5. & Lain-lain & 6 & $10 \%$ \\
\hline & \multicolumn{1}{|c|}{ Jumlah } & 60 & $100 \%$ \\
\hline
\end{tabular}

Tujuan wisatawan berkunjung ke obyek wisata alam Lava Bantal karena panorama atau keindahaan alamnya yang masih alami hal dikatakan $90 \%$ pengunjung. Sebanyak $10 \%$ pengunjung mengatakan karena sungai yang mengalir di obyek wisata tersebut sehingga penasaran untuk dikunjungi.

Tabel 9 : Tanggapan tentang kondisi jalan menuju ke Wisata Alam Lava Bantal \begin{tabular}{|l|l|l|l|}
\hline No. & Keterangan & Frek & Persentase \\
\hline
\end{tabular} 


\begin{tabular}{|c|l|c|c|}
\hline 1. & Kurang baik & 5 & $8,3 \%$ \\
\hline 2. & Cukup baik & 27 & $45 \%$ \\
\hline 3. & Baik & 26 & $43,3 \%$ \\
\hline 4. & Baik Sekali & 2 & $3,3 \%$ \\
\hline & Jumlah & 60 & $100 \%$ \\
\hline
\end{tabular}

Mengenai akses jalan menuju obyek wisata alam Lava Bantal kebanyakan responden atau wisatwan mengatakan cukup baik dengan prosentase $45 \%$ dan baik sebanyak $43,3 \%$ orang wisatawan. Pemerintah kabupaten Sleman telah membuatkan akses jalan yang baik dimana kondisi jalan sudah mulus. Hal ini dikarenakan akses jalan ini dilewati kendaraan dari obyek wisata Candi alam lava Bantal. Selain itu akses jalan menuju Bandara Internasional Adisucipto sehingga akses jalan dengan kondisi baik.

Tabel 10 : Tanggapan tentang Fasiltas Lahan Parkir Wisata Alam Lava Bantal

\begin{tabular}{|c|c|c|c|}
\hline No. & Keterangan & Frek & Persentase \\
\hline 1. & Kurang Baik & 7 & $11,6 \%$ \\
\hline 2. & Cukup Baik & 31 & $51,6 \%$ \\
\hline 3. & Baik & 22 & $36,6 \%$ \\
\hline & Jumlah & 60 & $100 \%$ \\
\hline
\end{tabular}

Mengenal lahan parker untuk kendaraan bahwa wisatawan menangapi kondisi lahan parker kendaraan roda dua dan roda empat memberikan penilaiaan yang cukup baik yaitu $51,6 \%$ dan mengatakan baik ada 36,6\% wisatawan. Pengelola obyek wisata telah memfasilitasi lahan parkir cukup baik. Apabila nanti obyek wisata ramai pengelola siap memberikan lahan yang masih cukup di belakang pendopo untuk sarana parkir.

Tabel 11 : Tanggapan tentang kebersihan

Lingkungan Wisata Alam Lava Bantal

\begin{tabular}{|c|l|c|c|}
\hline No. & Keterangan & Frek & Persentase \\
\hline 1. & Kotor & 11 & $18,3 \%$ \\
\hline 2. & Cukup bersih & 36 & $60 \%$ \\
\hline 3. & Bersih & 13 & $21,6 \%$ \\
\hline & Jumlah & 60 & $100 \%$ \\
\hline
\end{tabular}

Pengelola sadar betul bahwa masalah kebersihan di obyek wisata Lava Bantal adalah hal yang membuat pengunjung akan nyaman dan betah untuk menikmati pemandangan. Pengunjung mengatakan bahwa kebersihan di obyek wisata alam Lava Bantal sudah cukup bersih hal ini dikatakan oleh $60 \%$ pengunjung. Namun ada yang mengatakan masih kotor yaitu $18,3 \%$ pengunjung. Hal ini diakibatkan karena sungai Opak yang mengalir di Obyek ini kadang membawa sampah dari hulu sehingga terbawa sampai ke obyek wisata ini. Pengelola sudah menyediakan banyak sekali tempat sampah di obyek wisata ini sehingga pengunjung tidak sulit membuang sampah. Selain itu para petugas juga sering melakukan pembersihan sampah.

Tabel 12 : Tanggapan tentang keamanan di Wisata Alam Lava Bantal

\begin{tabular}{|l|l|l|l|}
\hline No. & Keterangan & Frek & Persentase \\
\hline
\end{tabular} Prambanan dan Boko menuju obyek wisata

\begin{tabular}{|c|l|c|c|}
\hline 1. & Tidak aman & 1 & $1,6 \%$ \\
\hline 2. & Mengkwatirkan & 3 & $5 \%$ \\
\hline 3. & Kurang aman & 26 & $43 \%$ \\
\hline 4. & Aman & 30 & $50 \%$ \\
\hline & Jumlah & 60 & $100 \%$ \\
\hline
\end{tabular}

Faktor keamanan adalah salah satu yang menentukan kenyamana para pengunjung wisata alam Lava Bantal dan pengelola wisata ini sangat serius memperhatikan masalah keamanan bagi pengunjungnya. Untuk masalah keamanan pengunjung masih mengkwatirkan dan merasa kurang aman jika pengunjung bermain disungai karena tidak ada petugas atau safe guard yang ada dipinggir sungai khususnya jika wisatawan membawa anak-anak kecil yang bermain air. Selain itu pinggir sungai yang tidak berpagar juga sempat dikwatirkan pengunjung jika berjalan di pinggir sungai. Namun untuk kegiatan Rivertubing faktor keamanan sudah berjalan baik karena pemandu sudah berpengalaman memandu peserta kegiatan Rivertubing ini.

Tabel 13 : Tanggapan tentang kepuasaan terhadap pelayanan petugas atau pengeloladi Wisata Alam Lava Bantal

\begin{tabular}{|c|c|c|c|}
\hline No. & Keterangan & Frek & Persentase \\
\hline 1. & $\begin{array}{l}\text { Tidak } \\
\text { memuaskan }\end{array}$ & 0 & $0 \%$ \\
\hline 2. & $\begin{array}{l}\text { Kurang } \\
\text { memuaskan }\end{array}$ & 25 & $41,6 \%$ \\
\hline 3. & Memuaskan & 35 & $58,3 \%$ \\
\hline & Jumlah & 60 & $100 \%$ \\
\hline
\end{tabular}

Pengelola wisata obyek wisata alam Lava Bantal dalam mengembangkan wisata ini selama ini telah melakukan peningkatan dalam pelayanan kepada pengunjung hal ini dilihat dalam penambahan fasilitas akses jalan yang diperlebar kemudian penambahaan saranaprasarana seperti tempat duduk dengan dibangunkan gazebo dan pendopo untuk acara-acara tertentu. Selama ini pengunjung tidak dikenai tiket masuk hanya biaya parkir atau titipan kendaraan saja. Penilaian pengunjung terhadap pelayanan dari pengelola obyek wisata ini mengatakan 58,3\% pengunjung memuaskan dan $41,6 \%$ yang mengatakan kurang memuaskan. Mereka yang mengatakan kurang memuaskan menginginkan sarana bermain anak atau playground sebagai pelengkap di obyek wisata ini. Kemudian ada penambahaan hot spot atau wifi internet.

Tabel 14 : Tanggapan tentang kepuasaan pengunjung selama berwisata di Wisata Alam Lava Bantal

\begin{tabular}{|c|c|c|c|}
\hline No. & Keterangan & Frek & Persentase \\
\hline 1. & $\begin{array}{l}\text { Tidak } \\
\text { memuaskan }\end{array}$ & 0 & $0 \%$ \\
\hline 2. & $\begin{array}{l}\text { Kurang } \\
\text { memuaskan }\end{array}$ & 22 & $36 \%$ \\
\hline 3. & Memuaskan & 38 & $64 \%$ \\
\hline & Jumlah & 60 & 60 \\
\hline
\end{tabular}


Dalam masalah kepuasaan para pengunjung yang menikmati wisata alam Lava Bantal menyatakan memuaskan di obyek wisata alam tersebut hal ini dikatakan 64\% pengunjung. Hal ini dikarenakan kenyaman dan keindahaan serta sarana prasarana yang mendukung di obyek wisata tersebut. Akses jalan yang cukup strategis sehingga memudahkan pengunjung datang ke obyek tersebut.

Tabel 15 : Tanggapan tentang keinginan pengunjung kembali lagi berkunjung ke Wisata Alam Lava Bantal

\begin{tabular}{|c|c|c|c|}
\hline No. & Keterangan & Frek & Persentase \\
\hline 1. & $\begin{array}{l}\text { Akan kembali } \\
\text { berkunjung }\end{array}$ & 46 & $76 \%$ \\
\hline 2. & Tidak Tahu & 16 & $24 \%$ \\
\hline & Jumlah & 60 & 100 \\
\hline
\end{tabular}

Dengan panorama yang masih alami, wisata alam Lava Bantal tetap memikat pengunjung ingin datang kembali, hal ini yang dikatakan $76 \%$ pengunjung. Hal ini disebabkan karena akses jalan yang mudah, saranaprasarana yang cukup memadai, kebersihan dan keamanan yang mendukung. Kemudian masih asri dan alami dan wisata ini cukup mendukung untuk menjadi wisata alam dan pendidikan bagi pengunjung khususnya anak muda yang sekarang hobi traveling. Persepsi pengunjung setelah berkunjung ke wisata alam Lava Bantal mengatakan bahwa obyek wisata masih bisa dikembangkan lebih besar hal ini sejalan dengan pemerintah desa yang mempunyai kewenangan mengelola obyek tersebut bahwa nantinya akan diperluas dari lahan parkir, sarana prasarana serta penyiapan sumber daya manusia.

Pengunjung wisata alam ini semakin hari semakin bertambah ramai saat libur panjang seperti lebaran dan akhir tahun atau cuti bersama membuat pengelola mulai giat untuk membangun jaringan ke biro tour and travel untuk mendatangkan wisatawan ke obyek tersebut. Kemudian ingin mengandeng sekolah-sekolah untuk mengharapkan para siswa-siswa untuk berwisata ke obyek ini karena alamnya bisa dijadikan bahan untuk pendidikan khsusunya ilmu pengetahuan alam hal ini dengan menjual batu-batu yang ada disekitar sungai yang bernilai sejarah.

Wisatawan sangat menilai perkembangan obyek wisata ini kian berkembang dengan startegi pengembangan yang baik menjadikan obyek wisata semakin menarik dikunjungi. Selain berwisata pendidikan alam mereka juga berwisata air dengan bermain air sungai yang tidak begitu deras serta yang mempunyai jiwa berpetualang mereka memanfaatkan untuk kegiatan rivertubing.

\subsection{Kesimpulan}

Dari hasil penelitian tentang i persepsi wisatawan terhadap obyek wisata alam Lava Bantal dapat disimpulkan sebagai berikut:

1. Persepsi wisatawan terhadapa obyek wisata alam Lava Bantal mengenai aspek sarana-prasarana sudah dinilai memadai bagi wisatawan yang berkunjung.

2. Persepsi wisatawan terhadap obyek wisata alam Lava Bantal mengenap aspek akses jalan menuju obyek wisata sudah baik dan sangat strategis lokasinya.

3. Persepsi wisatawan terhadap obyek wisata alam Lava Bantal tentang aspek kebersihan, keamanan dan kenyaman sudah dinilai bagus meski banyak kekurangan namun karena masih berkembang obyek wisata ini mereka memahami jika masih banyak kelemahan.

4. Persepsi wisatawan terhadap obyek wisata alam Lava Bantal tentang aspek pengelola obyek wisata mereka menilai sudah cukup baik hal ini dikaitkan dengan kepuasaan pengunjung untuk datang kembali ke obyek wisata ini.

5. Persepsi wisatawan terhadap obyek wisata alam Lava Bantal secara keseluruhan bahwa wisatawan berharap obyek wisata dapat dikembangkan lebih besar sehingga obyek wisata dapat terkenal dan menjadi kunjungan wisatawan lokal maupun internasional.

\section{Daftar Pustaka}

[1] Anonim, Undang-Undang Republik Indonesia Nomor 10 Tahun 2009 Tentang Kepariwisataan. Jakarta

[2] Endang Tjitroresmi, 2003. Peran Industri Kepariwisataan dalam Perekonomian Nasional dan Daerah Jakarta: P2E-LIPI.

[3] Fandeli, chafid.1995. Dasar-Dasar Manajemen Kepariwisataan Alam. Yogyakarta: Liberty

[4] M. Kesrul.2003. Penyelenggaraan Operasi Perjalanan Wisata. Jakarta : Grasindo

[5] Nyoman S.Pendit.1986. IImu Pariwisata. Jakarta : Pradnya Paramita.

[6] Pitana, I Gde dan Gayatri.2005. Sosiologi Pariwisata.Yogyakarta: Andi Offset.

[7] Salah Wahab, 1997. Turism Management. Jakarta, PT Pradnya Paramita.

[8] , $1989 . \quad$ Manajemen Kepariwisataan. Jakarta, PT Pradnya Paramita

[9] Siswantoro, Gamal.2001. Dasar-Dasar Pariwisata. Yogyakarta. Andi Offset 
[10]Walgito, Bimo.1999. Psikologi Sosial (Suatu Pengantar).Yogyakarta : Andi Offset

[11]Wardiyanta, 2006, Metode Penelitian Pariwisata, Yogyakarta : CV. Andi. Offset

[12]Yulianto, Atun. $2016 . \quad K i n e r j a$ Pengembangan Dan Pelayanan Candi
Ratu Boko Dalam Mendukung Kesempatan Usaha Masyarakat Setempat. Jurnal Khasanah IImu Vol. 7 No.1 Maret 2016. Yogyakarta : AKPAR BSI.

[13] http://jogja.tribunnews.com/2017/11/13/hin gga-bulan-oktober-6-juta-lebih-wisatawantelah-kunjungi-sleman. 16:38 WIB 